\title{
Hevea brasiliensis cell suspension peroxidase: purification, characterization and application for dye decolorization
}

\author{
Thitikorn Chanwun, Nisaporn Muhamad, Nion Chirapongsatonkul and Nunta Churngchow*
}

\begin{abstract}
Peroxidases are oxidoreductase enzymes produced by most organisms. In this study, a peroxidase was purified from Hevea brasiliensis cell suspension by using anion exchange chromatography (DEAE-Sepharose), affinity chromatography (Con A-agarose) and preparative SDS-PAGE. The obtained enzyme appeared as a single band on SDS-PAGE with molecular mass of $70 \mathrm{kDa}$. Surprisingly, this purified peroxidase also had polyphenol oxidase activity. However, the biochemical characteristics were only studied in term of peroxidase because similar experiments in term of polyphenol oxidase have been reported in our pervious publication. The optimal pH of the purified peroxidase was 5.0 and its activity was retained at $\mathrm{pH}$ values between 5.0-10.0. The enzyme was heat stable over a wide range of temperatures $\left(0-60^{\circ} \mathrm{C}\right)$, and less than $50 \%$ of its activity was lost at $70^{\circ} \mathrm{C}$ after incubation for $30 \mathrm{~min}$. The enzyme was completely inhibited by $\beta$-mercaptoethanol and strongly inhibited by $\mathrm{NaN}_{3}$; in addition, its properties indicated that it was a heme containing glycoprotein. This peroxidase could decolorize many dyes; aniline blue, bromocresol purple, brilliant green, crystal violet, fuchsin, malachite green, methyl green, methyl violet and water blue. The stability against high temperature and extreme $\mathrm{pH}$ supported that the enzyme could be a potential peroxidase source for special industrial applications.
\end{abstract}

Keywords: Cell suspension, Characterization, Decolorization, Hevea brasiliensis, Peroxidase, Purification

\section{Introduction}

Peroxidases (EC 1.11.1.7) are enzymes that oxidize various hydrogen donors in the presence of $\mathrm{H}_{2} \mathrm{O}_{2}$ or organic hydroperoxides. They catalyse many different and important biochemical and physiological reactions in most living organisms. Plant peroxidases are involved in diverse physiological functions such as lignin biosynthesis (Gross 2008), suberization (Bernards et al. 1999), wound healing (Kumar et al. 2007), fruit ripening (Huang et al. 2007), auxin metabolism and disease resistance (Veitch 2004). The peroxidase superfamily can be divided into three classes according to their origin, amino acid homology and metal-binding capability. Class I includes the plant intracellular peroxidases as well as prokaryotic enzymes from mitochondria and chloroplasts (Passardi et al. 2007). Class II comprises extracellular fungal peroxidases: lignin-degrading peroxidase (LiP), and

* Correspondence: nunta.c@psu.ac.th

Department of Biochemistry, Faculty of Science, Prince of Songkla University, Hat-Yai, Songkhla 90112, Thailand

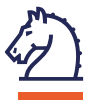

manganese peroxidase $(\mathrm{MnP})$, and includes monomeric glycoproteins involved in the degradation of lignin. Fungal LiP and MnP belonging to this class of peroxidases have been most commonly studied for dye decolorization. Class III consists of secretory plant peroxidases, with multiple tissue specific functions; e.g. removal of $\mathrm{H}_{2} \mathrm{O}_{2}$ from chloroplasts and cytosol, oxidation of toxic compounds, biosynthesis of cell walls, defence responses towards wounding, indole-3-acetic acid catabolism, ethylene biosynthesis, etc. Some of the most well known peroxidases in this class are the horseradish peroxidase (HRP), turnip peroxidase (TP), bitter gourd peroxidase (BGP) and soybean peroxidase (SBP). Class III peroxidases are also monomeric glycoproteins containing four conserved disulphide bridges, and require calcium ions for their activities (Schuller et al. 1996). Peroxidases from plant tissues are able to oxidize a wide range of phenolic compounds, such as o-dianisidine, guaiacol, pyrogallol, chlorogenic acid, catechin and catechol (Passardi et al. 2005). 
Peroxidases from different sources are of wide interest because of their extensive potential applications in the clinical, biochemical, biotechnological and industrial fields, and in the synthesis of useful compounds (e.g. various aromatic chemicals) (Srinivas et al. 2002). Because of their wide catalytic activities, these enzymes could be exploited for the detoxification and remediation of various aromatic pollutants; for example, phenols, aromatic amines, and dyes that have contaminated wastewater from the effluents of textile, printing, paper and pulp industries (Jadhav et al. 2009).

Peroxidases are found in vacuoles, tonoplasts, plasmalemma including inside and outside of the cell wall. These enzymes have been purified and studied from many plant sources; for example, oil palm (Deepa and Arumughan 2002), sweet potato tubers (Leon et al. 2002), melon (Rodriguez-Lopez et al. 2000), cauliflower (Koksal et al. 2008), rubber tree (Wititsuwannakul et al. 1997), baculovirus (Levin et al. 2005) and insect larvae (Loustau et al. 2008). In rubber trees (Hevea brasiliensis Willd. ex A. de Juss. Müell. Arg), peroxidase activity has been found in newly excised bark strips, possibly present in response to wounding (Wititsuwannakul et al. 1997).

In this report, a peroxidase was purified from cell suspensions of rubber tree using anion exchange chromatography, affinity chromatography and preparative SDS-PAGE. Unexpectedly, the purified peroxidase also possessed polyphenol oxidase activity inferring that it is a bifunctional enzyme. Since the properties of polyphenol oxidase was studied in the previous article (Muhamad et al. 2012), the purified enzyme was therefore analyzed based on the characteristics of peroxidase. The molecular weight of this peroxidase and some properties such as the effects of temperature, $\mathrm{pH}$, some inhibitors and its activity on the dye decolorization were also reported. The obtained peroxidase may be used as an alternative source in some industrial applications since it was heat stable up to $70^{\circ} \mathrm{C}$ and its activity was retained over a wide range of $\mathrm{pH}$ values (5.0-10.0).

\section{Materials and methods}

\section{$\boldsymbol{H}$. brasiliensis cell suspension and culture condition}

The cell suspension of $H$. brasiliensis was prepared according to Muhamad et al. (2012) and Te-chato et al. (2002). First, calli were cultivated from the integument of $\mathrm{H}$. brasiliensis seeds on Murashige and Skoog's (MS) medium containing 3\% (w/v) sucrose, $1 \mathrm{mg} / \mathrm{mL}$ of 2,4-dichlorophenoxy acetic acid (2,4-D) and $1 \mathrm{mg} / \mathrm{mL}$ of 6-benzylaminopurine (BA), pH 5.7 under dark conditions at $25 \pm 2^{\circ} \mathrm{C}$. The integument calli that developed were transferred to MS medium containing $2 \mathrm{mg} / \mathrm{mL}$ of $2,4-\mathrm{D}$ and $0.1 \mathrm{mg} / \mathrm{mL}$ of thidiazuron, pH 5.7 under controlled conditions for generating cell suspensions. The cells were subcultured to fresh medium every 14 days. The 28-day-old cell cultures were separated from the medium and stored at $-20^{\circ} \mathrm{C}$ for the total protein extraction and further purification of peroxidase.

\section{Protein extraction, protein determination and peroxidase activity assay}

Protein extraction was performed following some modifications of the procedure of Muhamad et al. (2012). Briefly, collected cells were ground with liquid $\mathrm{N}_{2}$ and extracted in $0.2 \mathrm{M}$ phosphate buffer, $\mathrm{pH} 6.5$, containing $0.25 \%(\mathrm{v} / \mathrm{v})$ Triton X-100 and 3\% (w/v) polyvinylpolypyrrolidone (PVPP). The supernatant was separated from the homogenate by centrifugation at $12,000 \mathrm{rpm}$ and $4^{\circ} \mathrm{C}$ for $15 \mathrm{~min}$. The protein content was measured by the Bradford method (Bradford 1976) using BSA as standard.

Peroxidase activity was assayed using a spectrophotometer according to (Shannon et al. 1996). The reaction mixture contained $2.775 \mathrm{~mL}$ of $0.05 \mathrm{M}$ sodium

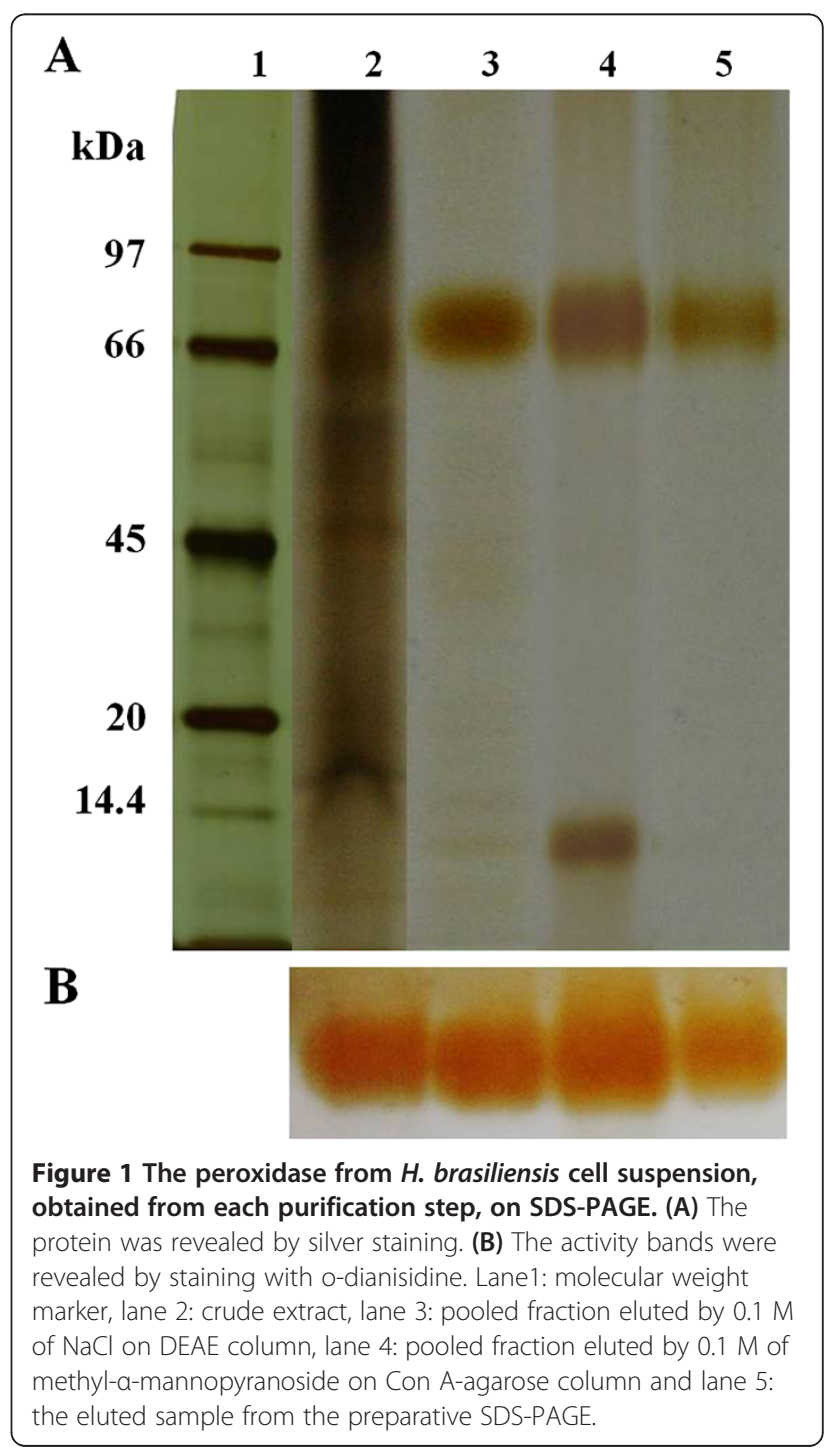




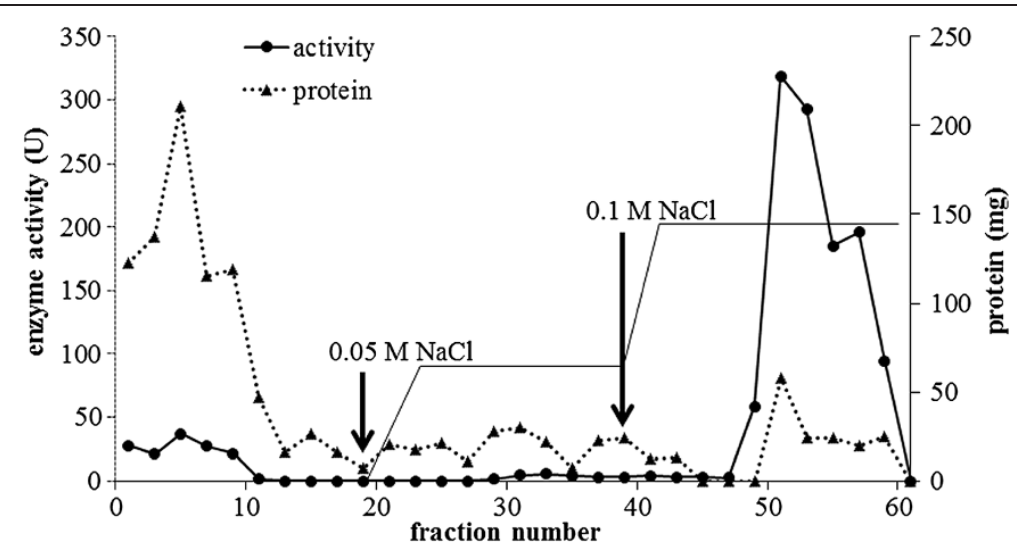

Figure 2 Purification of the peroxidase enzyme from $H$. brasiliensis cell suspension by anion-exchange chromatography on DEAEcellulose column and stepwise eluted by $0.05 \mathrm{M}$ and $0.1 \mathrm{M} \mathrm{NaCl}$. The arrows indicate the starting fraction that was eluted by each $\mathrm{NaCl}$ concentration. Each fraction was collected for $3 \mathrm{ml}$.

acetate buffer, $\mathrm{pH} 5.4,100 \mu \mathrm{L}$ of $0.25 \%(\mathrm{w} / \mathrm{v}) o$-dianisidine $\left(\varepsilon=11.3 \mathrm{mM}^{-1} \mathrm{~cm}^{-1}\right.$ at $\left.460 \mathrm{~nm}\right), 100 \mu \mathrm{L}$ of $0.1 \mathrm{M} \mathrm{H}_{2} \mathrm{O}_{2}$ and $25 \mu \mathrm{L}$ of enzyme solution. Absorbance at $460 \mathrm{~nm}$ was recorded every $15 \mathrm{~s}$ for $2 \mathrm{~min}$. The enzyme activity was calculated following the formula below:

Enzyme activity (unit $/ \mathrm{mL})=\frac{V t \times m}{\varepsilon \times D \times V}$ where $V t$ is the total volume of reaction $(\mathrm{mL}), V$ is the volume of enzyme $(\mathrm{mL}), m$ is the slope of the linear portion, $\varepsilon$ is the molar extinction coefficient and $D$ is the distance of the light pass which is $1 \mathrm{~cm}$.

\section{Purification of peroxidase}

The enzyme extract was subjected to a DEAE-Sepharose CL-6B column $(2.5 \mathrm{~cm} \times 5.0 \mathrm{~cm}$, GE Healthcare) equilibrated with $0.02 \mathrm{M}$ phosphate buffer, $\mathrm{pH} 8.0$, at $4^{\circ} \mathrm{C}$. Stepwise elution was done at a flow rate of $0.5 \mathrm{~mL} / \mathrm{min}$ with the same buffer containing 0.05 and $0.1 \mathrm{M} \mathrm{NaCl}$, respectively. The eluted fractions that exhibited high peroxidase activity were pooled and concentrated before loading onto a Con A-agarose column $(1.5 \mathrm{~cm} \times 1.5 \mathrm{~cm}$, GE Healthcare) equilibrated with a solution containing $0.5 \mathrm{M} \mathrm{NaCl}, 0.005 \mathrm{M} \mathrm{MgCl}, 0.005 \mathrm{M} \mathrm{MnCl} 2$ and $0.005 \mathrm{M} \mathrm{CaCl}_{2}$. The fractions with high peroxidase activity were eluted with $0.1 \mathrm{M}$ methyl.alpha;-mannopyranoside, concentrated and further purified by using preparative sodium dodecylsulfate- polyacrylamide gel electrophoresis (preparative SDSPAGE). A single band of protein was extracted from the gel and dialyzed against $0.02 \mathrm{M}$ phosphate buffer, $\mathrm{pH}$ 8.0.

\section{Tracking each step of peroxidase purification by} electrophoretic analysis

The SDS- PAGE was carried out according to the method of Laemmli (1970). The molecular weight of the purified peroxidase was estimated based on the molecular weight markers (Bio-Sciences) after silver staining (GE Healthcare). The activity band was revealed by incubating in the mixture containing 1 $\mathrm{mL}$ of $0.25 \%(\mathrm{w} / \mathrm{v})$ o-dianisidine, $1 \mathrm{~mL}$ of $0.1 \mathrm{M}$ $\mathrm{H}_{2} \mathrm{O}_{2}$ and $28 \mathrm{~mL}$ of $0.05 \mathrm{M}$ sodium acetate buffer, $\mathrm{pH}$ 5.4.

\section{Effect of temperature on enzyme stability}

The purified peroxidase was incubated at various temperatures $\left(0-80^{\circ} \mathrm{C}\right)$ for $30 \mathrm{~min}$ and then immediately put on ice. Enzyme activity was assayed as described above. The non-incubated enzyme was used as a control.

\section{Effect of $\mathrm{pH}$ on enzyme activity and stability}

The optimum $\mathrm{pH}$ of the purified peroxidase was assayed by measuring its activity in standard buffer solutions of

Table 1 Summary of the purification of the peroxidase isolated from a $\boldsymbol{H}$. brasiliensis cell suspension

\begin{tabular}{llllll}
\hline Purification step & $\begin{array}{l}\text { Total protein } \\
(\mathbf{m g})\end{array}$ & $\begin{array}{l}\text { Total activity } \\
(\mathbf{U})\end{array}$ & $\begin{array}{l}\text { Specific activity } \\
(\mathbf{U} / \mathbf{m g})\end{array}$ & $\begin{array}{l}\text { Purification factor } \\
\text { Yield } \\
(\%)\end{array}$ \\
\hline Crude & 10.810 & 18796.46 & 1738.75 & 1 & 100.00 \\
\hline DEAE & 0.213 & 797.95 & 3752.97 & 2.16 & 4.25 \\
\hline ConA-agarose & 0.061 & 355.25 & 5820.53 & 3.35 & 1.89 \\
\hline Prep-SDS-PAGE & 0.004 & 331.88 & 76872.67 & 44.21 & 1.77 \\
\hline
\end{tabular}



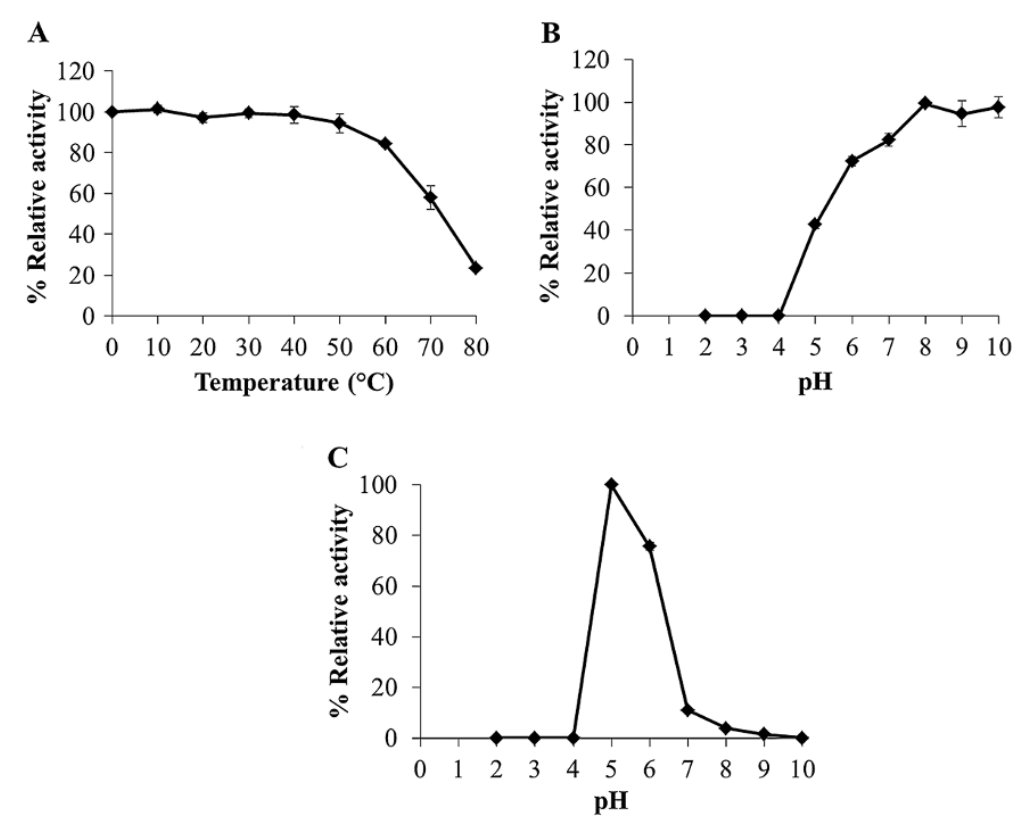

Figure 3 Effect of temperature and $\mathrm{pH}$ on the purified peroxidase: (A) temperature stability, (B) pH stability and (C) pH optimum.

different $\mathrm{pH}$ values (pH 2.0-10.0) (Fluka). The $\mathrm{pH}$ stability was studied by incubating the enzyme with various buffer solutions ( $\mathrm{pH} 2.0-10.0$ ) for $30 \mathrm{~min}$ and then assayed for its activity after adjusting the $\mathrm{pH}$ to 5.4. The non-incubated enzyme was used as a control.

Effect of various compounds on the peroxidase activity The purified peroxidase was incubated with several compounds (EDTA, $\beta$-mercaptoethanol, $\mathrm{NaN}_{3}$, and SDS) at a ratio of $1: 1(\mathrm{v} / \mathrm{v})$ for $5 \mathrm{~min}$. The enzyme was incubated with distilled water for use as a control, and the enzyme activity was assayed as described above.

The efficiency of the dye decolorization of the peroxidase The dyes used in this study included amido black, aniline blue, brilliant green, bromocresol purple, bromothymol blue, congo red, crystal violet, erioglaucine, fast green, fuchsin, malachite green, metanil yellow, methylene green, methyl green, methyl orange, methyl red, methyl violet, resazurin, safranin $\mathrm{T}$, toluidine blue $\mathrm{O}$, trypan blue and water blue. The dye decolorization was assayed following the modified method of Parshetti et al. (2012). The reaction mixtures were prepared in distilled water. One $\mathrm{mL}$ of reaction mixture, that contains dye, $0.001 \mathrm{M}$ of $\mathrm{H}_{2} \mathrm{O}_{2}$ and 25 units of the purified peroxidase, was incubated at room temperature and then the absorbance at the specific maximum wavelength of each dye was recorded at $24 \mathrm{~h}$. The maximum wavelengths for the studied dyes were: amido black (620 nm), aniline blue $(596 \mathrm{~nm})$, brilliant green $(626 \mathrm{~nm})$, bromocresol purple (437 nm), bromothymol blue (434 nm), congo red $(500 \mathrm{~nm})$, crystal violet $(590 \mathrm{~nm})$, erioglaucine (628 $\mathrm{nm})$, fast green $(624 \mathrm{~nm})$, fuchsin $(543 \mathrm{~nm})$, malachite green $(617 \mathrm{~nm})$, metanil yellow $(444 \mathrm{~nm})$, methylene green $(664 \mathrm{~nm})$, methyl green $(632 \mathrm{~nm})$, methyl orange $(457 \mathrm{~nm})$, methyl red $(457 \mathrm{~nm})$, methyl violet $(584 \mathrm{~nm})$, resazurin $(600 \mathrm{~nm})$, safranin $\mathrm{T}(521 \mathrm{~nm})$, toluidine blue $\mathrm{O}$ $(615 \mathrm{~nm})$, trypan blue $(595 \mathrm{~nm})$ and water blue $(596 \mathrm{~nm})$.

Table 2 Effect of various compounds on the activity of the purified peroxidase, the results are shown as a mean of remained activity \pm standard deviation of three replicates

\begin{tabular}{lll}
\hline Compounds & Concentration & \% Relative activity \\
\hline EDTA & $1 \mathrm{mM}$ & $85.43 \pm 11.48$ \\
\hline & $5 \mathrm{mM}$ & $91.05 \pm 8.58$ \\
\hline$\beta$-mercaptoethanol & $10 \mathrm{mM}$ & $69.06 \pm 10.01$ \\
\hline & $1 \mathrm{mM}$ & $82.98 \pm 4.76$ \\
\hline & $5 \mathrm{mM}$ & 0.00 \\
\hline $\mathrm{NaN}_{3}$ & $10 \mathrm{mM}$ & 0.00 \\
\hline & $1 \mathrm{mM}$ & $45.94 \pm 8.98$ \\
\hline $\mathrm{SDS}$ & $5 \mathrm{mM}$ & $25.18 \pm 4.90$ \\
\hline & $10 \mathrm{mM}$ & $18.99 \pm 3.31$ \\
\hline & $0.5 \%$ & $84.75 \pm 5.20$ \\
\hline & $2.0 \%$ & $86.51 \pm 4.69$ \\
\hline
\end{tabular}


Table 3 Application of purified peroxidase on dye decolorization

\begin{tabular}{|c|c|c|c|}
\hline Groups & General chemical formula & Dyes & Decolorization effect \\
\hline \multirow[t]{3}{*}{$\overline{\mathrm{Azo}}$} & $R$ & Methyl orange & - \\
\hline & $\mathrm{N}=$ & Methyl red & - \\
\hline & 1 & Metanil yellow & - \\
\hline \multirow[t]{3}{*}{ Diazo } & & Amido black & - \\
\hline & & Congo red & - \\
\hline & & Trypan blue & - \\
\hline Oxazine & & Resazurin & - \\
\hline Phenazine & & Safranin & - \\
\hline \multirow[t]{3}{*}{ Phenothiazine } & & Methylene green & - \\
\hline & & Toluidine blue $\mathrm{O}$ & - \\
\hline & & & + \\
\hline \multirow[t]{12}{*}{ Triphenylmethane } & & Aniline blue & \\
\hline & & Brilliant green & + \\
\hline & & Bromocresol purple & + \\
\hline & & Bromothymol blue & - \\
\hline & & Crystal violet & + \\
\hline & & Erioglaucine & - \\
\hline & & Fast green & - \\
\hline & & Fuchsin & + \\
\hline & & Malachite green & + \\
\hline & & Methyl green & + \\
\hline & & Methyl violet & + \\
\hline & & Water blue & + \\
\hline
\end{tabular}

+ represent positive result of dye decolorization.

- represent negative result of dye decolorization.

The decolorization was carried out with different starting amounts of each dye adjusted to provide the initial absorbance of 0.8-0.9 at its own specific wavelength. The percentage of the decolorization was calculated by the following formula;

\%Decolorization $=\frac{O D u-O D t}{O D u} \times 100$ where $O D u$ is the absorbance of untreated while $O D t$ is the absorbance of the treated dye at the desired incubation time. The decolorization process of each dye was observed in triplicate. The dye decolorization efficiency was analyzed by one-way ANOVA with the confidence level of $95 \%$.

\section{Results}

Purification of peroxidase

Several bands of peroxidase in the crude extract of $H$. brasiliensis cell suspension were detected after activity staining. The level of the major band increased with the age of the cell suspension (data not shown). The 28-day -old cell suspensions of $H$. brasiliensis were selected for the starting source for the peroxidase purification. Throughout this work, the peroxidase activity and activity staining (Figure 1B) was determined using $o$-dianisidine as the substrate. Three steps used for the purification included anion exchange chromatography (DEAE column), affinity 


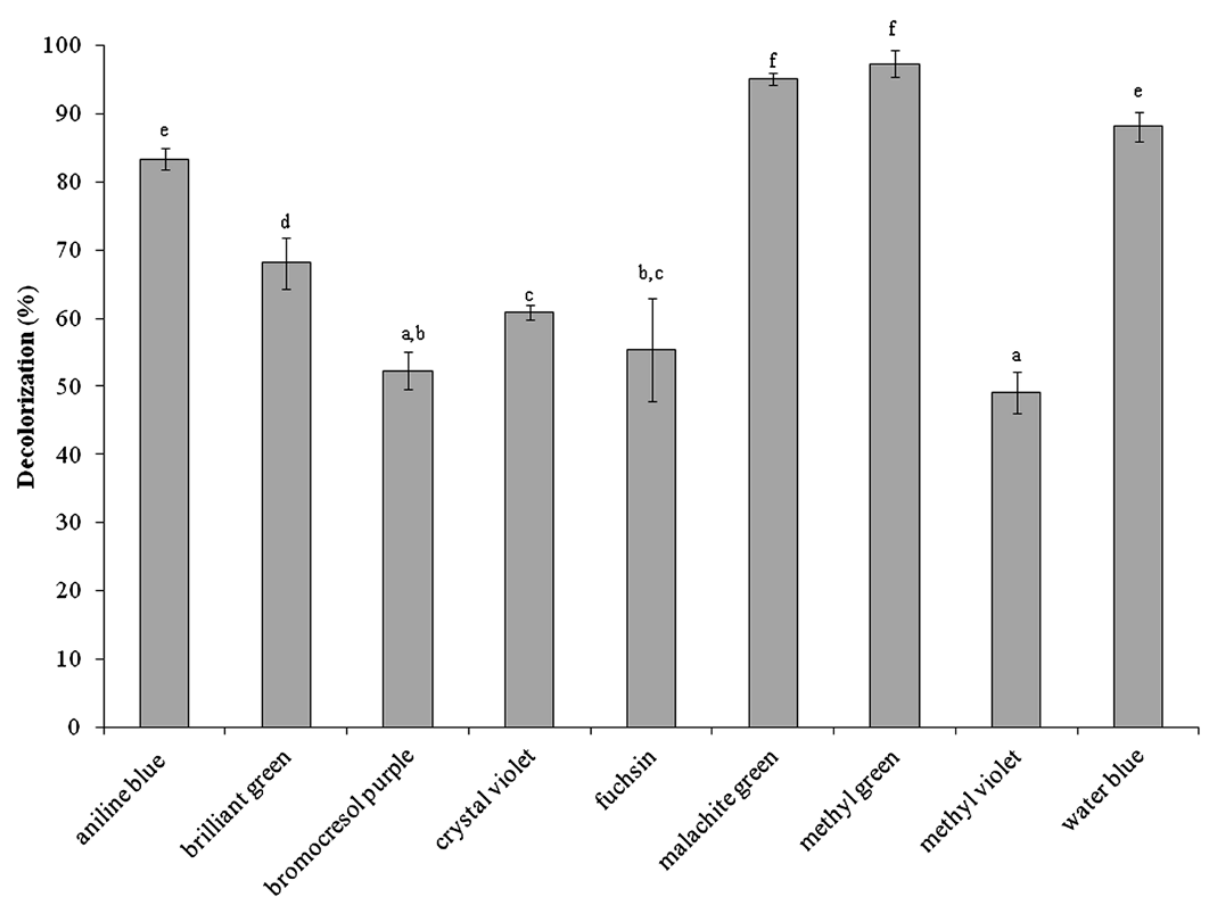

Figure 4 The decolorization of tested dyes in triphenylmethane group. Each bar represents mean \pm standard deviation and letters a, b, c, d, $e$ and $f$ represent different level of significance of each dye $(p<0.05)$.

chromatography (Con A-agarose column) followed by a preparative SDS-PAGE. From the DEAE column, fractions 50-60, eluted with $0.1 \mathrm{M} \mathrm{NaCl}$, possessed the highest peroxidase activity (Figure 2). Those eluted fractions were pooled, concentrated and then transferred onto the Con A-agarose column. The fraction eluted with $0.1 \mathrm{M}$ of methyl-alpha;-mannopyranoside exhibited two bands on SDS-PAGE (Figure 1A). After further purification through the preparative SDS-PAGE, a single band that with a 44 fold increased in its specific activity was obtained (Figure 1A, Lane 5, Table 1). The purification steps, total activity, specific activity, purification factor and percentage of yield are summarized in Table 1. The molecular weight of the obtained peroxidase was 70 $\mathrm{kDa}$ according to the molecular weight markers on SDS-PAGE (Figure 1A).

\section{Optimum $\mathrm{pH}$ and effect of $\mathrm{pH}$ and temperature on the enzyme stability}

The effect of $\mathrm{pH}$ on the activity of the purified peroxidase was determined over the range of $\mathrm{pH}$ between 2.0 and 10.0. The optimum $\mathrm{pH}$ of the purified enzyme was 5.0 (Figure 3C). For $\mathrm{pH}$ stability, the enzyme activity started to lose at $\mathrm{pH}$ below 7.0 and it was completely abolished at $\mathrm{pH}$ 2.0-4.0 (Figure 3B). The effect of temperature, $0-80^{\circ} \mathrm{C}$, on the enzyme activity was also examined. The purified peroxidase retained $57 \%$ of its relative activity at $70^{\circ} \mathrm{C}$ (Figure $\left.3 \mathrm{~A}\right)$.

\section{Effect of various compounds on peroxidase activity}

The effect of various compounds on peroxidase acti vity was determined at room temperature. The result showed that this enzyme was completely inhibited by $\beta$-mercaptoethanol and strongly inhibited by $\mathrm{NaN}_{3}$, slightly inhibited by EDTA and SDS (Table 2).

\section{The efficiency of the peroxidase to catalyse dye decolorization}

The purified peroxidase ( 25 units) was tested for its ability to decolorize dyes that have been reported as contaminants in wastewaters from textile, plastic, paper industries and laboratory. The different groups of tested dyes included azo dye: methyl orange, methyl red and metanil yellow; diazo dye: amido black, congo red and trypan blue; oxazine dye: resazurin; phenazine dye: safranin $\mathrm{T}$; phenothiazine dye: methylene green, toluidine blue $\mathrm{O}$; and triphenylmethane dye: aniline blue, brilliant green, bromocresol purple, bromothymol blue, crystal violet, erioglaucine, fast green, fuchsin, malachite green, methyl green, methyl violet and water blue. Most of triphenylmethane dyes were decolorized while the other tested groups were not reacted (Table 3). Among these 
triphenylmethane dyes, various decolorization activities within $24 \mathrm{~h}$ were shown in Figure 4, aniline blue (83\%), brilliant green $(68 \%)$, bromocresol purple $(52 \%)$, crystal violet (60\%), fuchsin (55\%), malachite green (95\%), methyl green (97\%), methyl violet (49\%) and water blue $(88 \%)$. However, all of the dyes in Figure 4 were decolorized to a clear solution after incubation for $72 \mathrm{~h}$.

\section{Discussion}

A peroxidase enzyme from $H$. brasiliensis cell suspension was extracted, purified and characterized by determination of some of its biochemical properties and application in the dye decolorization. The results showed that the peroxidase was relatively easily purified through three steps, anion exchange chromatography (DEAESepharose), affinity chromatography (Con A-agarose) then followed by preparative SDS-PAGE. The binding of the enzyme to the Con A-agarose column indicated that the peroxidase was a glycoprotein compatible with the previous studies reporting that most of the plant peroxidases were glycoproteins (Johansson et al. 1992; Kvaratskhelia et al. 1997; Passardi et al. 2005). Our purified peroxidase had a molecular weight of $70 \mathrm{kDa}$ as determined by SDS-PAGE while the molecular weights of various peroxidases have been reported to be in the range of $30-150 \mathrm{kDa}$ (Regalado et al. 2004). A similar molecular weight for the purified peroxidase has been previously reported from Pseudomonas sp. SUK1 (86 $\mathrm{kDa})$, Leptogium saturninum (79 kDa) and Kocuria rosea MTCC 1532 (66 kDa), (Kalyani et al. 2011; Liers et al. 2011; Parshetti et al. 2012). The molecular weight of this obtained peroxidase was equal to those of the polyphenol oxidase previously characterized in our laboratory (Muhamad et al. 2012); however, at that time the peroxidase staining was not attempted. Now, the duplicated gels were stained with substrates of each enzyme and elucidated that it possessed the activities of both enzymes. By the mentioned purification procedure, the obtained protein also exhibited high activity of polyphenol oxidase inferring that it is a bifunctional enzyme. The bifunctional activity (peroxidase-polyphenol oxidase) also appeared in Satsuma mandarin, turnip and Brassica oleracea L. (Fujita et al. 1980a, 1980b; Rahman et al. 2012). However, the fact that whether our purified protein is a single protein chain exhibiting both activities of peroxidase and polyphenol oxidase is being pursued to elucidate. In this report the enzyme was studied in term of peroxidase since our previous work has reported the biochemical characteristics of polyphenol oxidase enzyme (Muhamad et al. 2012). The optimal pH of the purified enzyme was 5.0 which were close to those reported from Jatropha curcas, Streptomyces sp. and L. leucocephala (Cai et al. 2012; Fodil et al. 2012; Pandey and Dwivedi 2011). For pH stability, its activity was retained at $\mathrm{pH}$ values between 5.0 and 10.0, and it had no activity at a $\mathrm{pH}<4.0$. Previous studies have reported that peroxidases lose their activities at low $\mathrm{pH}$ due to the instability of the heme molecule bound to the enzyme (Adams and Gorg 2002). Our purified peroxidase likewise contains heme groups since a peak of its spectrum was present at $302 \mathrm{~nm}$ (data not shown) which similar to the spectrum of other purified peroxidases containing heme groups (Gold et al. 1984; Kalyani et al. 2011; Tien and Kent Kirk et al. 1984). Moreover, the enzyme was heat stable over a wide range of temperatures $\left(0-60^{\circ} \mathrm{C}\right)$, and about $40 \%$ of its activity was lost at $70^{\circ} \mathrm{C}$ within $30 \mathrm{~min}$. The heat stability of this enzyme was similar to the peroxidases isolated from Jatropha curcas, artichoke and Euphobia cotinifolia (Cai et al. 2012; Cardinali et al. 2011; Kumar et al. 2011). The effect of various compounds on this peroxidase showed $\beta$-mercaptoethanol strongly inhibited its activity. This results indicated that at least one disulfide bond within the structure was important for its activity. Schuller et al. (1996) has reported that Class III peroxidases are monomeric glycoproteins; containing four conserved disulphide bridges. Our peroxidase was also the glycoprotein which contains disulphide bonds; therefore our enzyme may belong to class III peroxidase. The $\mathrm{NaN}_{3}$ could strongly inhibit this peroxidase. This chemical substance has been reported to be an inhibitor for all peroxidases (Pandey and Dwivedi 2011) as it can coordinate with the metal ion of a metal enzyme causing toxicity (Schwartz et al. 2001), for example, $\mathrm{NaN}_{3}$ acts as an inhibitor on a peroxidase from Jatropha curcas and Viscum angulatum (Cai et al. 2012; Das et al. 2011). Our purified enzyme was slightly inhibited by EDTA, a chelating agent, like those from Jatropha curcas and Viscum angulatum (Cai et al. 2012; Das et al. 2011). In addition, SDS which is a strong anionic detergent slightly inhibited its activity probably due to a conformational change of the enzyme. The enzymatic decolorization of dyes by this purified enzyme was examined using a UV-vis spectrophotometer. The results showed that the enzymatic activity could decolorize the triphenylmethane dye group. Aniline blue, malachite green, methyl green and water blue were rapidly decolorized (83-97\%) within 24 $\mathrm{h}$. This enzyme also decolorized brilliant green, bromocresol purple, crystal violet, fuchsin and methyl violet (49-68\%) within $24 \mathrm{~h}$, and the residuals were then cleared within $72 \mathrm{~h}$. Recently, it has been reported that many aromatics dyes can be decolorized by peroxidase through the precipitation or breaking of the aromatic ring structure (Husain 2010). Many previous studies have also reported that bacterial and fungal peroxidases from, for example, Phanerochaete chrysosporium and Bjerkandera adusta could decolorize dyes (Bumpus and Brock 1988; Mohorčič et al. 2006). However using 
microorganisms to decolorize dyes involves high costs, alternative sources such as plants are now being considered. Our purified peroxidase could react on extreme condition, so it may be used as an alternative enzyme to treat water pollutants. Our study provided a new perspective for the use of this enzyme or a related system in environmental biotechnology. Further studies will focus on the purification and characterization of peroxidase enzymes from other tissues of $H$. brasiliensis such as leaves and on the identification of the products obtained from the decolorization process by this enzyme.

\section{Competing interests}

The authors declare that they have no competing interests.

\section{Acknowledgments}

This work was supported by the Office of the Higher Education Commission of Thailand for funded to Ms. Thitikorn Chanwun, by a grant from the Biochemistry Excellence Strengthening Program and by the Research Funding from the Graduate School of Prince of Songkla University. We thank Dr. Brian Hodgson, Faculty of Science, Prince of Songkla University, for comments and assistance with the English.

\section{Received: 30 January 2013 Accepted: 5 February 2013}

Published: 12 February 2013

\section{References}

Adams CD, Gorg S (2002) Effect of pH and gas-phase ozone concentration on the decolorization of common textile dyes. J Environ Eng 128:293-298

Bernards MA, Fleming WD, Llewellyn DB, Priefer R, Yang X, Sabatino A, Plourde GL (1999) Biochemical characterization of the suberization-associated anionic peroxidase of potato. Plant Physiol 121:135-146

Bradford MM (1976) A rapid and sensitive method for the quantitation of microgram quantitiesof protein utilizing the principle of protein dye binding. Anal Biochem 72:248-254

Bumpus JA, Brock BJ (1988) Biodegradation of crystal violet by the white rot fungus Phanerochaete chrysosporium. Appl Environ Microbiol 54:1143-1150

Cai F, Chao O, Peipei D, Shun G, Ying X, Fang C (2012) Purification and characterization of a novel thermal stable peroxidase from Jatropha curcas leaves. J Mol Catal B Enzym 77:59-66

Cardinali A, Tursi N, Ligorio A, Giuffrida MG, Napolitano L, Caliandro R, Sergio L, Di Venere D, Lattanzio V, Sonnante G (2011) Purification, biochemical characterization and cloning of a new cationic peroxidase isoenzyme from artichoke. Plant Physiol Biochem 49:395-403

Das MK, Sharma RS, Mishra V (2011) A novel cationic peroxidase (VanPrx) from a hemi-parasitic plant (Viscum angulatum) of Western Ghats (India): Purification, characterization and kinetic properties. J Mol Catal B Enzym 71:63-70

Deepa SS, Arumughan C (2002) Purification and characterization of soluble peroxidase from oil palm (Elaeis guineensis Jacq) leaf. Phytochemistry 61:503-511

Fodil D, Abdelmalek B, Bassem J, Nedia Z, Fatma ZF, Houcine B (2012) Purification and characterization of two extracellular peroxidases from Streptomyces sp. Strain AM2, a decolorizing actinomycetes responsible for the biodegradation of natural humic acids. Int Biodeterior Biodegradation 65:470-478

Fujita S, Tono T (1980a) Peroxidase activity of phloroglucin oloxidase from Satsuma mandarin fruits and effect of metal ions on the enzyme activity. Nippon Nogeikagaku Kaishi 54:201-208

Fujita S, Tono T (1980b) Purification of phloroglucinoloxidase from turnip and its properties. Nippon Nogeikagaku Kaishi 54:429-435

Gold MH, Kuwahara M, Chiu AA, Glenn JK (1984) Purification and characterization of an extracellular hydrogen peroxide requiring diarylpropane oxygenase from the white rot basidiomycete, Phanerochaete chrysosporium. Arch Biochem Biophys 234:353-362

Gross GG (2008) From lignins to tannins: Forty years of enzyme studies on the biosynthesis of phenolic compounds. Phytochemistry 69:3018-3031
Huang R, Xia R, Hu L, Lu Y, Wang M (2007) Antioxidant activity and oxygenscavenging system in orange pulp during fruit ripening and maturation Sci Hortic 113:166-172

Husain Q (2010) Peroxidase mediated decolorization and remediation of wastewater containing industrial dyes: a review. Rev Environ Sci Biotechnol 9:117-140

Jadhav UU, Dawkar W, Telke AA, Govindwar SP (2009) Decolorization of Direct Blue GLL with enhanced lignin peroxidase enzyme production in Comamonas sp UVS. J Chem Technol Biotechnol 84:126-132

Johansson A, Rasmussen SK, Harthill JE, Welinder KG (1992) cDNA, amino acid and carbohydrate sequence of barley seed-specific peroxidase B P 1 . Plant Mol Biol 18:1151-1161

Kalyani D, Phugare S, Shedbalkar U, Jadhav J (2011) Purification and characterization of a bacterial peroxidase from the isolated strain Pseudomonas sp. SUK1 and its application for textile dye decolorization. Ann Microbiol 61:483-491

Koksal E, Gulcin I (2008) Purification and characterization of peroxidase from cauliflower (Brassica oleracea L. var. botrytis) buds. Protein Pept Lett 15:320-326

Kumar S, Dutta A, Sinha AK, Sen J (2007) Cloning, characterization andlocalization of a novel basicperoxidase gene from Catharanthus roseus. FEBS J 274:1290-1303

Kumar R, Singh KA, Singh VK, Jagannadham MV (2011) Biochemical characterization of a peroxidase isolated from Caribbean plant: Euphorbia cotinifolia. Process Biochem 46:1350-1357

Kvaratskhelia M, Winkel C, Thorneley RN (1997) Purification and characterization of a novel class III peroxidase isoenzyme from tea leaves. Plant Physiol 114:1237-1245

Laemmli UK (1970) Cleavage of structural proteins during the assembly of the head of bacteriophage T4. Nature 277:680-685

Leon JC, Alpeeva IS, Chubar TA, Galaev IY, Csoregi El, Sakharov IY (2002) Purification and substrate specificity of peroxidase from sweet potato tubers, Plant Sci 163:1011-1019

Levin G, Mendive F, Targovnik HM, Cascone O, Miranda MV (2005) Genetically engineered horseradish peroxidase for facilitated purification from baculovirus cultures by cation-exchange chromatography. J Biotechnol 118:363-369

Liers C, Ullrich R, Hofrichter M, Minibayeva FV, Beckett RP (2011) A heme peroxidase of the ascomyceteous lichen Leptogium saturninum oxidizes highredox potential substrates. Fungal Genet Biol 48:1139-1145

Loustau MN, Romero LV, Levin GJ, Magri ML, López MG, Taboga O, Cascone O, Miranda MV (2008) Expression and purification of horseradish peroxidase in insect larvae. Process Biochem 43:103-107

Mohorčič M, Teodorovič S, Golob V, Friedrich J (2006) Fungal and enzymatic decolourisation of artificial textile dye baths. Chemosphere 63:1709-1717

Muhamad N, Chirapongsatonkul N, Churngchow N (2012) Defense-related polyphenol oxidase from Hevea brasiliensis cell suspension: Purification and characterization. Appl Biochem Biotechnol 167:177-189

Pandey VP, Dwivedi UN (2011) Purification and characterization of peroxidase from Leucaena leucocephala, a tree legume. J Mol Catal B Enzym 68:168-173

Parshetti G, Parshetti S, Kalyani D, R-a D, Govindwar S (2012) Industrial dye decolorizing lignin peroxidase from Kocuria rosea MTCC 1532. Ann Microbiol 62:217-223

Passardi F, Cosio C, Penel C, Dunand C (2005) Peroxidases have more functions than a Swiss army knife. Plant Cell Rep 24:255-265

Passardi F, Bakalovic N, Teixeira FK, Margis-Pinheiro M, Penel C, Dunand C (2007) Prokaryotic origins of the non-animal peroxidase superfamily and organellemediated transmission to eukaryotes. Genomics 89:567-579

Rahman ANF, Ohta M, Nakatani K, Hayashi N, Fujita S (2012) Purification and characterization of polyphenol oxidase from Cauliflower (Brassica oleracea L.). J Agric Food Chem 60:3673-3678

Regalado C, García-Almendárez BE, Duarte-Vázquez MA (2004) Biotechnological applications of peroxidases. Phytochem Rev 3:243-256

Rodriguez-Lopez JN, Espin JC, del Amor F, Tudela J, Martinez V, Cerda A, Garcia-Canovas F (2000) Purification and kinetic characterization of an anionic peroxidase from melon (Cucumis melo L.) cultivated under different salinity conditions. J Agric Food Chem 48:1537-1541

Schuller DJ, Ban N, van Huystee R, McPherson A, Poulos TL (1996) The crystal structure of peanut peroxidase. Structure 4:311-321

Schwartz B, Olgin AK, Klinman JP (2001) The role of copper in topa quinone biogenesis and catalysis, as probed by azide inhibition of a copper amine oxidase from yeast. Biochemistry 40:2954-2963 
Shannon ML, Kay E, Lew JY (1996) Peroxidase isozyme from horseradish root. J Biochem 9:2166-2172

Srinivas ND, Barhate RS, Raghavarao KSMS (2002) Aqueous two-phase extraction in combination with ultrafiltration for downstream processing of Ipomoea peroxidase. J Food Eng 54:1-6

Te-chato S, Hilae A, Yeedum I (2002) Improve callus induction and embryogenic callus formation from cultured young leaves of oil palm seedling. Thai J Agric Sci 35:407-413

Tien M, Kent Kirk T (1984) Lignin-degrading enzyme from Phanerochaete chrysosporium: Purification, characterization, and catalytic properties of a unique $\mathrm{H}_{2} \mathrm{O}$ requiring oxygenase. Proc Natl Acad Sci USA 81:2280-2284

Veitch NC (2004) Horseradish peroxidase: a modern view of a classic enzyme. Phytochemistry 65:249-259

Wititsuwannakul R, Wititsuwannakul D, Sattaysevana B, Pasitkul P (1997) Peroxidase from Hevea brasiliensis bark: purification and properties. Phytochemistry 44:237-241

doi:10.1186/2191-0855-3-14

Cite this article as: Chanwun et al:: Hevea brasiliensis cell suspension peroxidase: purification, characterization and application for dye decolorization. AMB Express 2013 3:14

\section{Submit your manuscript to a SpringerOpen ${ }^{\circ}$ journal and benefit from:}

- Convenient online submission

- Rigorous peer review

- Immediate publication on acceptance

- Open access: articles freely available online

- High visibility within the field

- Retaining the copyright to your article

Submit your next manuscript at $\gg$ springeropen.com 